\title{
English summaries / danske resuméer
}

English summaries of Danish- and German-language articles / danske resuméer af engelsk- og tysksprogede artikler

\section{Grundtvigs vej til Saxo}

Flemming Lundgreen-Nielsen

\author{
Grundtvig's Path to Saxo
}

This article documents Grundtvig's path to the works of Saxo Grammaticus from around 1787, when he was taught to read by his strongwilled mother, and until departure from Saxo after completing his translation of Saxo's chronicle in 1823. An overview of this period focuses on the significant dates, book titles, and other points of interest that mark his interest in the medieval clerical scribe's work. Attention then turns to the fact that, after 1823, Grundtvig never seriously returned to study of Saxo's ideas, nor did he ever try to reproduce his silver age Roman style in the Danish language. For a very short while, Grundtvig thought about but never followed through on a continuation of a history of Denmark from where Saxo stopped (viz. in 1186). Though Grundtvig's preoccupation with Saxo lasted for the rest of his life, he preferred the Icelandic tongue instead of Latin and believed that Norse mythology was a more fertile field than Latin for discoveries about the national history of the Danes. The present survey of these key points in how Grundtvig viewed and evaluated Saxo also supplements previous scholarly treatments of stylisticlinguistic analyses of Grundtvig's youth translation of Saxo. 


\title{
Grundtvigs indflydelse på samfundet
}

\author{
Jes Fabricius Moller
}

\section{Grundtvig's Impact on Society}

This article revisits the assumption commonly made in literature about the significance of N.F.S. Grundtvig to Danish society, that his importance hardly can be overrated. In a re-evaluation of his influence 1) on the Danish welfare state, 2) on the first folk high schools, and 3) on the Danish constitution of 1849 , the study comes to the following mainly negative conclusions: 1) While he is credited for intitiating the Danish welfare state model, in fact, he did not want poor relief to be financed by a general tax. Grundtvig is often quoted as saying that there are "a few having too much, and fewer too little." This statement is often misinterpreted to mean that Grundtvig desired a matrix for general state driven egalitarian redistribution of funds. The opposite is true. 2) While he is called the creator of the folk high school, the fact is that the first advanced school for peasants in the Oldenburg Monarchy was erected in Rendsburg in 1842. It sparked the initiative to establish a similar school for Danes in Rødding (established 1844), which was only indirectly inspired by Grundtvig. In 1856 a public donation celebrating his 70 th birthday three years earlier enabled Grundtvig to open a folk high school in his own name. However, he did not have much to do with it. The ties between the folk high school movement and Grundtvig did not grow stronger until the 1860's. 3) And finally, regarding Grundtvig's role in the creation of the 1849 constitution, Grundtvig favoured freedom of speech and belief. It has been argued that liberalism in general and John Locke in particular inspired him. And Grundtvig has been canonized as one of the fathers of Danish democracy and as a champion of freedom in general. In fact, however, he spoke out in favour of absolutism as late as 1850 . If Grundtvig is to be interpreted as a contender of natural law, the possible inspiration from Thomas Hobbes must be taken into consideration. Having undeniably strong traits of liberalism in his political portfolio, the elements of conservatism cannot be ignored 


\title{
The Deep Coinherence: An Attempt to Understand N.F.S. Grundtvig's Holistic Vision
}

\author{
Wen Ge
}

Den dybe sammenhæng. Et forsøg på at forstå

N.F.S. Grundtvigs holistiske vision

\begin{abstract}
Artiklen tager sit udgangspunkt i Grundtvigs udtryk "den dybe Sammenhæng", som oversættes med "the deep coinherence". Syndefaldet har i nogen grad ødelagt den dybe sammenhæng i Gud-menneske-naturen, især hvad angår forholdet mellem Guds ord og menneskets ord. Grundtvigs synspunkt er, at menneskelivets utydelighed må få klarhed gennem inkarnationen af det ord, som åbenbarer det sande billede af Gud i tro, håb og kærlighed. Når den apostolske trosbekendelse lyder ved dåben, optages et menneske i en levende menighed ved et ord, der bærer vidnesbyrd om en levende tradition. På den måde bliver den kristne åndeligt forenet med Kristus og påbegynder det kristelige liv. Grundtvig tillægger også menneskelivet en selvstændig værdi. Med udgangspunkt i sin mosaisk-kristelige antropologi slår han til lyd for, at det guddommelige-menneskelige forhold viser sig i ordets fortsatte skabende proces uden for kristendommen. Hans opfattelse er, at dette er han enig med naturalisterne om. Ved således at stadfæste betydningen af det naturlige skabte menneskeliv stræber Grundtvig efter måder at vække åndeligt døde mod en længsel efter evigheden, så de kan være rede til med frie levende menneske-ord at møde Guds ord. Dette viser Kristi tilknytning til skabelsen. Der er snæver forbindelse mellem det skabende og det inkarnerede ord. Dette er den dybe sammenhæng mellem skabelse og genløsning i den historiske proces.
\end{abstract}


Grundtvigs gudstjenestesyn liturgisk teologisk ny-beskrevet Jette Bendixen Rønkilde

\section{A Liturgical Theological Re-reading of Grundtvig's View on Worship}

Through a description of well-known works by Grundtvig, the article examines how Grundtvig's view on worship can be said to form an independent liturgical theological position, which the author characterizes as a theory of communication of worship. The examination takes the AngloAmerican theory of worship, Liturgical Theology, as its starting point. Then, Grundtvig's view on worship is reinterpreted against main currents and main issues of contemporary Liturgical Theology. The article demonstrates how structures in the works of Grundtvig and in liturgical theology parallel each other, an observation that frames Grundtvig as a proto liturgical theologian. Grundtvig's specific liturgical theological position is firmly rooted in a trinitarian understanding of worship as a meeting place between God and human beings and the experience of worship as intrinsically bound to aesthetic experience. Grundtvig's view of worship can therefore be deemed to be in keeping with an aesthetic Trinitarian view that significantly emphasizes the third article of faith in the patristic symbols and the practice of the assembly. 


\section{Et melopoetisk greb på Grundtvigsalmen}

\section{Lea Wierød}

\section{A Melopoetic Approach to Grundtvig's Hymns}

The church hymns written by N.F.S. Grundtvig are simultaneously poems, theological statements and music, but they have predominantly been the subjects of theological research and, to a lesser extent, literary research. Musicological research has avoided literary critique of the texts of hymns and, as a result, has nearly reduced itself to a theological-literary subdiscipline. Hymn scholarship maintains an underlying logocentricsm, which follows conceptions of the text as the actual hymn and the melody as its subsidiary facilitator. These conceptions are implicit in the use of the genitive in the phrase "Grundtvig's church hymns." However, this perspective can be defended neither on the basis of Grundtvig's own hymnological poetics or through contemporary aesthetic theories about how signification is produced in medially mixed utterances, like the church hymn. In this article the author seeks to question the place of church hymns in hierarchies of word-music by shifting focus from the issue of "to what degree does this particular melody redeem Grundtvig's text" to "what significance is produced from the merging of words and melody in the hymn during its situational utterance". 